\title{
Forage Responses of Buffelgrass and 'Pretoria 90' Bluestem to Nitrogen and Phosphorus Fertilization in a Subtropical Climate
}

\author{
R.P. WIEDENFELD, W.T.W. WOODWARD, AND R.R. HOVERSON
}

\begin{abstract}
A major land use, especially in drier areas of subtropical regions is for forage production. Nutrient availability, as well as moisture, limit production; however, little is known concerning optimum fertilization practices and how nutrient use interacts with rainfall to affect forage yields. A study was conducted on a sandy upland soil under subtropical conditions to determine the effects of nitrogen $(\mathrm{N})$ and phosphorus (P) fertilization on yield, rainfall use efficiency, nutrient uptake, and apparent fertilizer recovery on improved pastures. Established buffelgrass showed dramatic yield responses to $\mathbf{N}$ application, while newly planted Pretoria 90 bluestem showed yield responses to $\mathrm{N}$ only after residual nutrients had been depleted. Yield responses to $\mathbf{N}$ application were mostly quadratic, showing decreasing benefit from $N$ with increasing $N$ application rate. Smaller yield responses to $P$ occurred in the first 2 years on Pretoria 90 and at higher $\mathbf{N}$ application rates on buffelgrass. Rainfall use efficiency (yield per unit of rainfall received) for buffelgrass increased greatly with increasing $\mathbf{N}$ application rate. Rainfall use efficiency of newly planted Pretoria 90 increased during each of the first 3 years as the stand developed, but was not greatly affected by $\mathbf{N}$ fertilization level. Nutrient contents in both grasses generally increased with increasing nutrient application. Both $\mathbf{N}$ and $\mathbf{P}$ removal by buffelgrass increased primarily with increasing $N$ application. Apparent $N$ and $P$ fertilizer use efficiency by both grasses was affected very little by rate of application of either nutrient but increased with increasing annual rainfall.
\end{abstract}

Forage production is a major land use in subtropical regions, and numerous management techniques are employed to enhance yield and quality. Improved pastures substantially increase production potential. Forage production is largely relegated to the more arid areas, therefore, moisture availability is often a major constraint on yield potentials. Warm temperatures accelerate nutrient cycling in the ecosystem and increase nutrient requirements.

Improved pastures have been established on much of the mixedbrush rangeland in the South Texas resource area known as the Rio Grande Plain. Buffelgrass (Cenchrus ciliaris L.) is a droughttolerant, subtropical perennial bunchgrass and occupies more than 90\% of the area seeded to grasses in Texas south of San Antonio (Holt and Bashaw 1976). Buffelgrass has high yields (Woodward $1980 \mathrm{~b}$ ); however, its range is limited by lack of cold tolerance and low survival on poorly drained soils. 'Pretoria 90' bluestem (Dichanthium annulatum (Forsk.) Stapf.) is also a subtropical perennial bunchgrass that is well adapted to subtropical areas (Conrad 1976, McBee 1959, Woodward 1980a); however, poor seed production has prevented Pretoria 90 from becoming used extensively.

Fertilization should benefit forage production in subtropical areas; however, little has been done to determine specific requirements or magnitude of responses. Nutritional quality of unfertilized buffelgrass in native rangeland pasture in South Texas varies

\footnotetext{
Authors are assistant professor, former assistant professor (currently director. Department of Alfalfa Breeding. Pioneer Hi-Bred International, Inc., Johnston, lowa), and former area specialist (currently a private consultant, Mercedes, Texas), Texas A\&M University Agricultural Research and Extension Center. Weslaco 78596. This study is a contribution of the Texas Agricultural Experiment Station, Texas A\&M University, College Station 77843 and was partially supported by Metz and Kappler, Edinburg; American Agri-Services, Elsa; and Tide Products, Edinburg.

Manuscript accepted July 23, 1984.
}

seasonally but is typically low (Gonzalez and Everett 1982). Improvements in forage quality with fertilization have been shown in the Northern Great Plains (Hansen et al. 1978, Black and Wight 1979, Lutwick and Smith 1979) and could also be expected in more southern regions. Reports of fertilizer uptake efficiency by forages varies widely from 8-14\% (Lutwick and Smith 1979) and 25-43\% (Hansen et al. 1978) in the northern regions, to $40-50 \%$ on a clay soil (Kissel et al. 1979) and up to $100 \%$ on coarser textured soils (Prine and Burton, 1965) in more southern areas. Fertilization has also been shown to increase soil water extraction by forages and to improve water use efficiency (Wight and Black 1978, Williams et al. 1979).

This study was conducted to evaluate the effects of nitrogen and phosphorus fertilization on yield, rainfall use efficiency, nutrient uptake, and apparent fertilizer recovery of 2 forage grasses under subtropical conditions.

\section{Materials and Methods}

A field study was established in the spring of 1979 to evaluate forage responses under subtropical conditions to various fertilization treatments. The study was located in northwest Hidalgo County on a Hebbronville soil (coarse-loamy, mixed, hyperthermic Aridic Haplustaif), a gently sloping, rapidly permeable, sandy upland soil. The area is semiarid, receiving approximately $500 \mathrm{~mm}$ rainfall annually with peaks occurring in May and August, and subtropical with an annual growing season of 315 days. The area selected had a well-established stand of common buffelgrass which had not received fertilizer in recent years. Part of the area was disked to remove the buffelgrass and to provide a good seedbed. Pretoria 90 bluestem seedlings, which were started in potting media in a greenhouse, were transplanted in the disked area on 25 May. Plants were spaced at $0.5 \mathrm{~m}$ in rows $1 \mathrm{~m}$ apart. Approximately 1 liter of water was applied to each plant four days after planting and within 2 weeks over $5 \mathrm{~cm}$ of rainfall ensured survival of the seedlings.

Plots 3.1 by 10.2 were established on each area for annual fertilizer treatments consisting of 0,112 , and $224 \mathrm{~kg} \mathrm{~N} / \mathrm{ha}$ and 0,15 and $29 \mathrm{~kg} \mathrm{P} / \mathrm{ha}$ combined in a factorial arrangement. The 9 treatments were replicated 4 times in a randomized complete block design for each grass. All fertilizers were applied broadcast, with $\mathbf{P}$ applied in 1 application in the spring each year as triple super phosphate (0-44-0), and $\mathrm{N}$ annually applied as ammonium nitrate (33-0-0) in 3 split applications once in the spring and after each of the first 2 harvests.

Soil samples were taken in the spring of each year prior to fertilization from 1979 through 1983 to a depth of $30 \mathrm{~cm}$. In 1979 , soil samples were taken at random throughout the area for each grass, and in subsequent years soil samples were taken from each plot. These soil samples were analyzed for $\mathrm{NO}_{3}{ }^{-} \mathrm{N}$ by specific ion electrode in a water extract from 1979 to 1981, and by Kjeldahl distillation (Bremner 1965) in 1982 and 1983. Available $P$ was extracted with ammonium acctatc at $\mathrm{pH} 4.2$ and then the chlorostannous-reduced molybdophosphoric blue color method was used in a hydrochloric acid system (Jackson 1970) to determine $P$ concentration. 


\section{BUFFELGRASS}
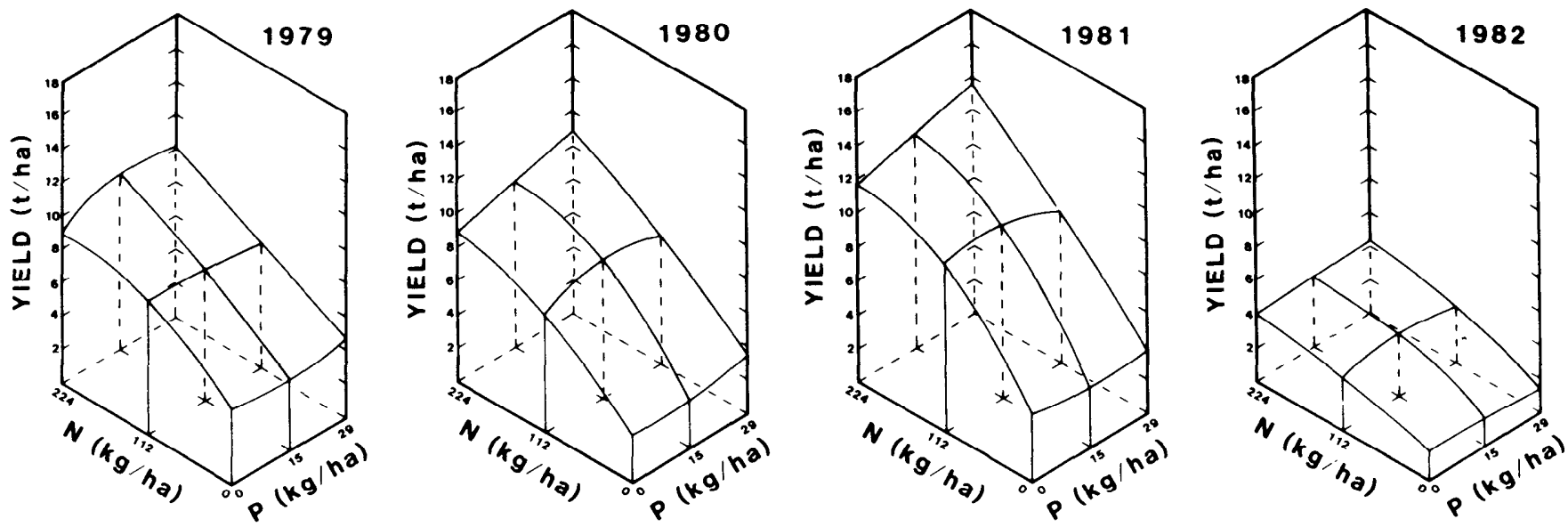

Fig. 1. Annual yields for an established stand of buffelgrass at the different $N \&$ P application levels for 4 years.

Yields were determined by harvesting all plots 2 to 4 times each year. A strip, $1 \mathrm{~m}$ wide by $8.2 \mathrm{~m}$ long, was cut from each plot using a flail-type small-plot harvester and samples were weighed to determine wet weight. Subsamples were dried to correct wet weights for the moisture percentage of each sample. The forage subsamples were then ground and analyzed for $\mathbf{N}$ and $P$ content. Nitrogen was determined by a sulfuric-salicylic acid digestion and Kjeldahl distillation (Jackson 1970), and $\mathrm{P}$ was determined by a nitric-sulfuricperchloric acid digestion and a vanadomolybdophosphoric yellow color method in a nitric acid system (Jackson 1970).

Forage yields and tissue analyses were used to calculate the total amount of $\mathbf{N}$ and $\mathbf{P}$ removed in the harvest. Apparent fertilizer recovery was calculated as the amount of each nutrient in the forage harvested minus the amount removed from the check plot for that block where no fertilizer was applied, divided by the amount of the nutrient applied in the fertilizer.

Statistical analyses were applied to all data. The stepwise procedure of the SAS data analysis system (SAS Institute, Inc. 1982) was used to determine models which indicated the effects of $\mathrm{N}$ and $\mathrm{P}$ fertilization on forage yield, $\mathrm{N}$ and $\mathrm{P}$ rcmoval, and apparent $\mathrm{N}$ and $P$ fertilizer recovery. Annual rainfall was included in yield models combining data for all years. Variables were included in each model if they were statistically significant at the $10 \%$ confidence level. Analysis of variance and mean separation using Duncan's multiple range test were used to evaluate the effects of fertilization on yield per unit of rainfall and forage $N$ and $P$ contents at the individual harvest dates.

\section{Results and Discussion}

Soil tests in the spring of 1979 indicated that $\mathrm{NO}_{3}{ }^{-} \mathrm{N}$ levels of less than 5 ppm throughout the study area were extremely low. In the subsequent years $\mathrm{NO}_{3}{ }^{-} \mathrm{N}$ levels showed slight increases of up to 8 to $10 \mathrm{ppm}$ at the high $\mathrm{N}$ application levels, if previous year rainfall had been low. There was no indication of any accumulation of inorganic $\mathrm{N}$ in the soil throughout the study. Phosphorus levels in 1979 were initially low averaging 5 ppm where the Pretoria 90 was planted, and medium averaging $23 \mathrm{ppm}$ where the buffelgrass plots were located. No consistent changes in soil $P$ were found in subsequent years that could be associated with fertilizer treatments.

Buffelgrass yields increased significantly in all years with increasing $\mathrm{N}$ application (Fig. 1). Phosphorus application significantly increased buffelgrass yields only in 1980 and 1981 , and only at the high $\mathrm{N}$ application level. Pretoria 90 bluestem yields increased overall in the first 3 years of the study indicating stand improvement (Fig. 2). Nitrogen application increased Pretoria 90 yields, however, only in the third year, 1981. In 1982, Pretoria 90 yields were very low because of the lack of timely rainfall, and the insignificant fertilizer responses probably resulted from some

\section{PRETORIA 90}
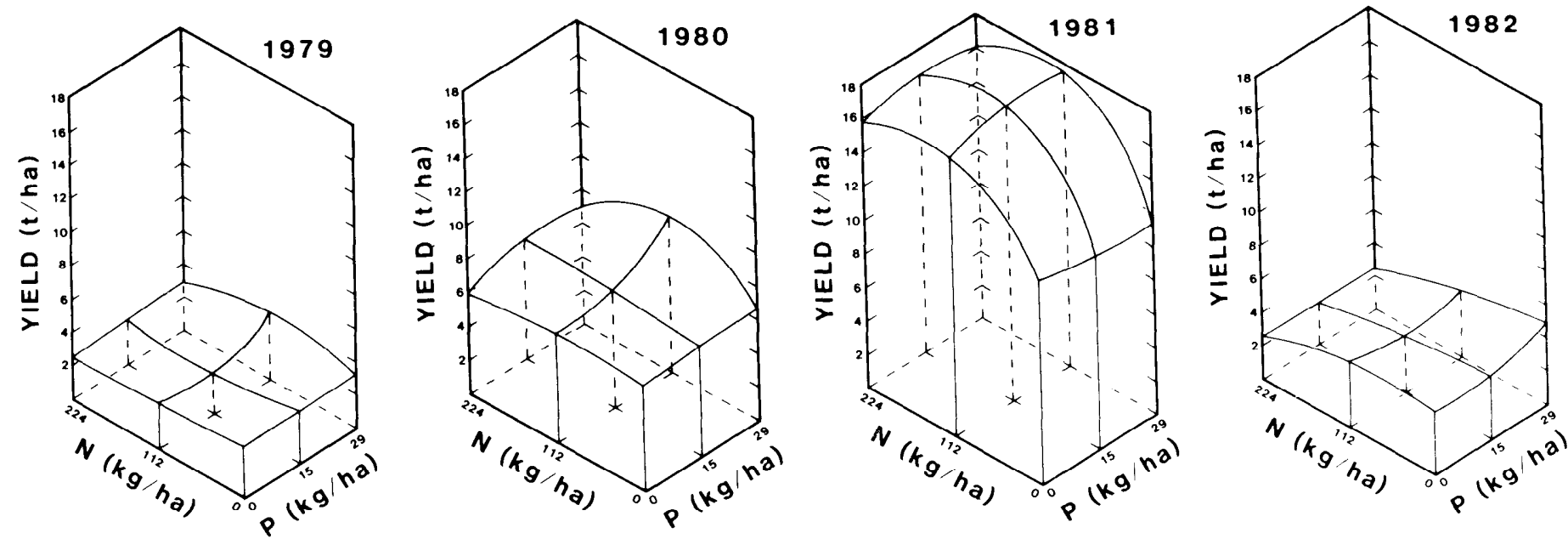

Fig. 2. Annual yields for a stand of Pretoria 90 bluestem planted in the spring of 1979 at the different $N$ and $P$ application levels for 4 years. 


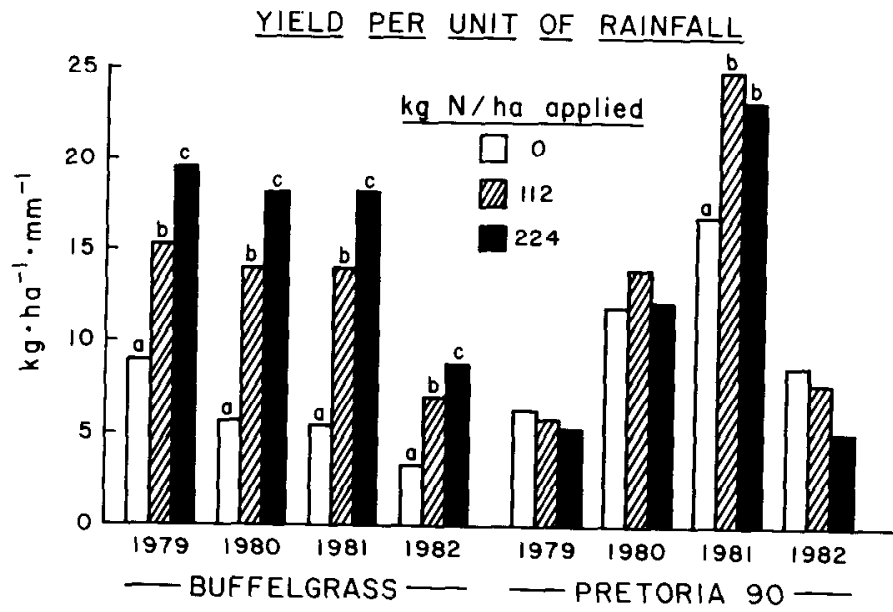

Fig. 3. Annual yields per unit of rainfall at the various $N$ application rates averaged across $P$ application rates for buffelgrass and Pretoria 90 bluestem for 4 years. Different letters above each bar indicate significant ( $\mathrm{p}<0.05$ ) differences between $N$ applications for each species within year.

freeze damage during the previous winter. The final harvest in 1981 had been made on 2 December and winter injury observed in the spring of 1982 appeared to be greatest where the higher $\mathrm{N}$ applications had been made. Phosphorus application increased Pretoria 90 yields slightly the first 2 years of this study.

Annual yield responses to increasing $\mathrm{N}$ application by buffelgrass were linear in 1979 and quadratic in 1980 through 1982. Pretoria 90 yield response to $\mathrm{N}$ application was also quadratic in 1981 , the only year a significant $\mathrm{N}$-fertilizer response was observed. These quadratic yield responses had a negative parameter estimate for $\mathrm{N}^{2}$ indicating that yield increases per unit of $\mathrm{N}$ decreased with increasing $\mathrm{N}$ application level.

Annual rainfall strongly influenced overall yields. Rainfall was fairly evenly distributed during the growing season in 1979 and 1981 , though total rainfall was greater in 1981. Much of the annual rainfall in 1980 came in the fall, while almost half of the 1982 total was received in a brief period during May. Regression yield models

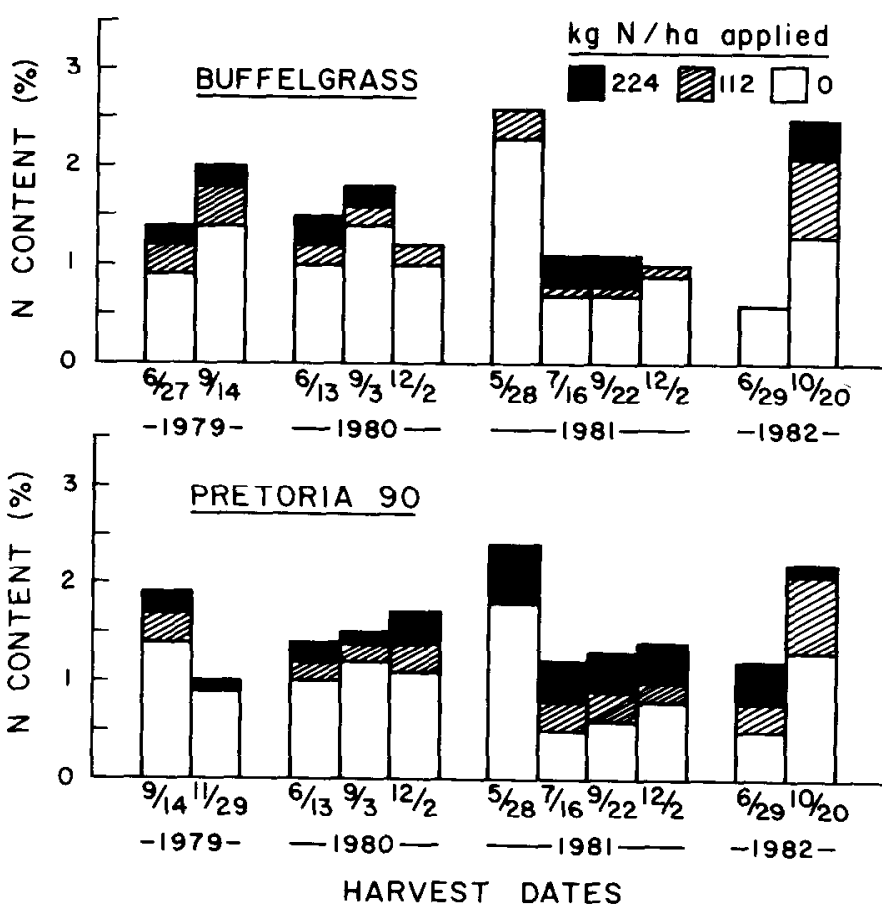

Fig. 4. Forage $N$ content of buffelgrass and Pretoria 90 bluestem at different $N$ application rates averaged across $P$ application rates for the various harvest dates.

combining all years and including annual rainfall (Table 1) indicated that buffelgrass yields were increased $18 \mathrm{~kg} /$ ha per $\mathrm{mm}$ of rainfall. The rainfall parameter estimate in the Pretoria 90 yield model was confounded by stand development as rainfall increased the first 3 years. The $R^{2}$ values for the yield models declined when the annual models were combined, indicating the degree of variation between years which could not be explained by annual rainfall.

Increasing $\mathrm{N}$ application caused a significant increase in yield of

Table 1. Regression model $R^{2}$ and parameter estimates for buffelgrass and Pretoria 90 bluestem yields and $N$ and $P$ removal as functions of $N$ and $P$ application. Yield models including all years also contained annual rainfall (Rain) as an independent variable.

\begin{tabular}{|c|c|c|c|c|c|c|c|c|c|}
\hline \multirow[b]{2}{*}{ Grass } & \multirow[b]{2}{*}{ Year } & \multirow[b]{2}{*}{$R^{2}$} & \multicolumn{7}{|c|}{ Parameter Estimates } \\
\hline & & & Intcrcept & $\mathbf{N}$ & $N^{2}$ & $\mathrm{P}$ & $P^{2}$ & $\mathbf{N} \times \mathbf{P}$ & Rain \\
\hline & & & & & 071 & -1 & $\ldots$ & -1 & \\
\hline $\begin{array}{l}\text { Buffelgrass } \\
\text { Pretoria } 90\end{array}$ & All & .67 & 6742 & 40.5 & -.074 & -1 & & .154 & 18.0 \\
\hline Pretoria 90 & All & .86 & -24910 & - & - & - & - & .146 & 57.5 \\
\hline \multirow[t]{4}{*}{ Buffelgrass } & 1979 & .89 & 53.0 & .482 & - & $\begin{array}{l}\text { al }- \\
-\end{array}$ & - & - & \\
\hline & 1980 & .86 & 34.4 & .623 & -.00083 & - & 一 & .00360 & \\
\hline & 1981 & .90 & 46.1 & 1.027 & -.00130 & - & - & - & \\
\hline & 1982 & .93 & 13.7 & .250 & -.00057 & - & - & .00159 & \\
\hline \multirow[t]{4}{*}{ Pretoria 90} & 1979 & .09 & 38.7 & - & - & - & .00824 & - & \\
\hline & 1980 & .49 & 68.0 & .349 & -.00120 & - & & .00380 & \\
\hline & 1981 & .28 & 146.2 & - & - & - & - & - & \\
\hline & 1982 & .34 & 29.6 & .166 & -.00058 & .159 & - & - & \\
\hline \multirow[t]{4}{*}{ Buffelgrass } & 1979 & .39 & 10.1 & .050 & $\begin{array}{r}-\mathrm{PF} \\
-.00017\end{array}$ & - & - & .00038 & \\
\hline & 1980 & .78 & 5.9 & .060 & -.00017 & - & - & .00092 & \\
\hline & 1981 & .76 & 7.7 & .067 & -.00023 & 080 & - & .00075 & \\
\hline & 1982 & .76 & 3.6 & .027 & -.00009 & - & - & .00056 & \\
\hline \multirow[t]{4}{*}{ Pretoria 90} & 1979 & .14 & 5.3 & - & - & - & .00182 & - & \\
\hline & 1980 & .45 & 6.3 & - & - & - & .00366 & - & \\
\hline & 1981 & .66 & 14.0 & - & - & .202 & - & .00091 & \\
\hline & 1982 & .66 & 4.9 & - & -.00004 & .102 & - & - & \\
\hline
\end{tabular}

'Missing parameter estimates indicate that the variable was not statistically significant and was not included in the model. 
Table 2. Regression model $R^{2}$ and parameter estimates for $\mathbf{N}$ and $P$ fertilizer use efficiency as functions of $N$ and $P$ application.

\begin{tabular}{|c|c|c|c|c|c|c|c|c|}
\hline \multirow[b]{2}{*}{ Grass } & \multirow[b]{2}{*}{ Year } & \multirow[b]{2}{*}{$R^{2}$} & \multicolumn{6}{|c|}{ Parameter Estimates } \\
\hline & & & Intercept & $\mathbf{N}$ & $N^{2}$ & $\mathbf{P}$ & $P^{2}$ & $\mathbf{N} \times \mathbf{P}$ \\
\hline & & & & $-\mathrm{N}$ & er use eff & - & - & 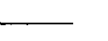 \\
\hline \multirow[t]{4}{*}{ Buffelgrass } & 1979 & $-\omega^{-1}$ & - & - & - & - & - & - \\
\hline & 1980 & - & - & - & - & - & - & - \\
\hline & 1981 & - & - & - & - & - & - & - \\
\hline & 1982 & .49 & 20.1 & - & -.00017 & .196 & - & - \\
\hline \multirow[t]{4}{*}{ Pretoria 90} & 1979 & .19 & -2.0 & - & - & - & .012 & - \\
\hline & 1980 & .52 & 7.7 & - & - & 2.296 & - & -.00855 \\
\hline & 1981 & .09 & 52.1 & - & - & - & .054 & - \\
\hline & 1982 & .20 & 12.2 & - & -.00017 & - & - & - \\
\hline \multirow{5}{*}{ Buffelgrass } & & & & & er use eff & & & \\
\hline & 1979 & .33 & 1.80 & - & .00085 & - & - & -.00487 \\
\hline & 1980 & .17 & 6.39 & .071 & - & - & - & - \\
\hline & 1981 & .25 & 8.63 & .074 & - & - & - & - \\
\hline & 1982 & .32 & 2.44 & 1.50 & -.00049 & - & - & 一 \\
\hline \multirow[t]{2}{*}{ Pretoria 90} & 1979 & - & - & - & - & - & - & - \\
\hline & 1980 & - & - & - & - & - & - & - \\
\hline \multirow[t]{2}{*}{ Pretoria 90} & 1981 & .11 & 21.0 & - & - & - & - & .00304 \\
\hline & 1982 & - & - & - & - & - & - & - \\
\hline
\end{tabular}

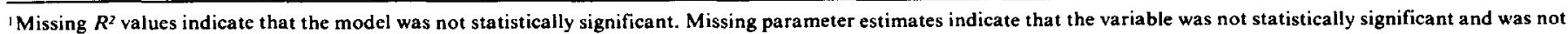
included in the model.

buffelgrass per unit of rainfall, or rainfall use efficiency every year (Fig. 3). Rainfall use efficiency for buffelgrass increased by an average of 2.2 and 2.8 times at 112 and $224 \mathrm{~kg} \mathrm{~N} /$ ha, respectively, over the control during the 4 years of the study. Rainfall use efficiency for forage production by Pretoria 90 was as great or greater than that by buffelgrass at 0 and $112-\mathrm{kg} \mathrm{N} /$ ha during 1980 and 1981. An increase in rainfall use efficiency with increasing $\mathbf{N}$ application occurred with Pretoria 90 only in 1981 at the $112-\mathrm{kg}$ $\mathrm{N} /$ ha rate.

Significant increases $(p<0.05)$ in N content with increasing $N$ application occurred for both grasses at most harvests (Fig. 4). Relatively large increases in Pretoria $90 \mathrm{~N}$ contents with increasing $\mathrm{N}$ application occurred although few corresponding yield responses were found. Increasing $\mathbf{N}$ uptake by buffelgrass with increasing $\mathbf{N}$ application was expressed more in yield increases than as increases in forage $\mathbf{N}$ content. Phosphorus applications had no effect on forage $\mathrm{N}$ content.

Forage $\mathrm{P}$ content increased significantly $(p<0.05)$ at most harvests with increasing $P$ application (Fig. 5). The forage $P$ content of the grass rarely, however, reached the level of $0.22 \%$ considered adequate for beef cattle diets (Whitman 1980). As with $N$, increases in forage $P$ levels reflected increases in uptake by both grasses that did not result in increased yicld.

Forage $P$ content of buffelgrass also decreased significantly in all years with increasing $\mathrm{N}$ applied, an effect not observed for Pretoria 90 . This effect of $\mathrm{N}$ application on buffelgrass is probably the result of dilution of the $\mathbf{P}$ taken up, as yields increased dramatically with increasing $\mathbf{N}$ applied. This dilution of $\mathbf{P}$ did not occur for Pretoria 90 since yield responses to applied $\mathrm{N}$ were much lower.

Nitrogen removal by buffelgrass increased with increasing $\mathrm{N}$ application in 1980 through 1982 in a quadratic fashion that indicated a decrease in $\mathrm{N}$ removal per unit of $\mathrm{N}$ applied as $\mathrm{N}$ application rate was increased (Table 1). Phosphorus application alone had no effect on $N$ removal by buffelgrass. But $N$ and $P$ in 1980 and 1982 had an interactive effect, indicating that $P$ application resulted in an increased $\mathbf{N}$ removal by buffelgrass at higher $\mathbf{N}$ application levels. Nitrogen removal by Pretoria 90 increased with increasing $N$ application in 1980 through 1982, and was also increased by applied $\mathrm{P}$ alone or as an interactive effect in 3 of the 4 years.

Phosphorus removal by buffelgrass increased quadratically with
$\mathrm{N}$ application (Table 1). Phosphorus application had an interactive effect with $\mathbf{N}$ on buffelgrass $\mathbf{P}$ uptake every year, showing that as $\mathbf{N}$ application increased, $P$ application began to increase buffelgrass $P$ removal. Removal of $\mathbf{P}$ by Pretoria 90 was unaffected by $N$ application, but was increased with increasing $P$ application each year.

Apparent recovery of both $\mathbf{N}$ and $\mathbf{P}$ fertilizer by either grass was not greatly affected by rate of fertilizer application. Nitrogen fertilizer recovery by both grasses was decreased in 1982 with increasing $\mathrm{N}$ applied, and was increased in some years on both grasses with
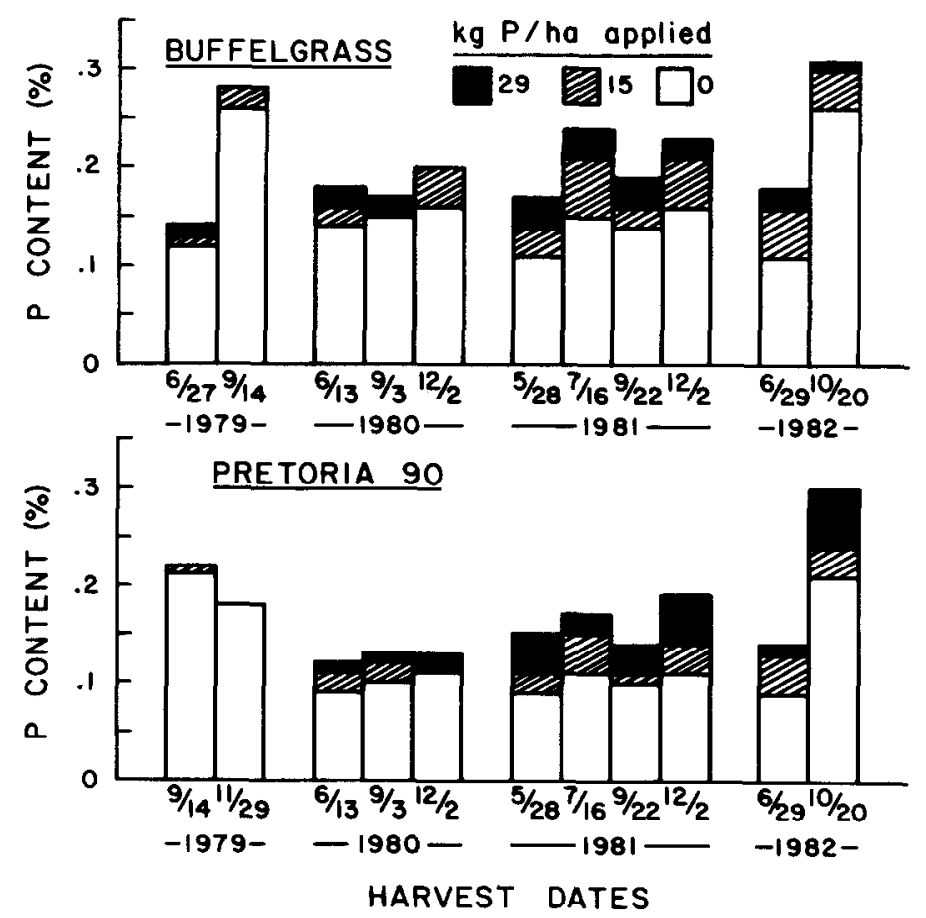

Fig. 5. Forage $P$ content of buffelgrass and Pretoria 90 bluestem at different $P$ application rates averaged across $N$ application rates for the various harvest dates. 
increasing $\mathbf{P}$ applied (Table 2). Phosphorus fertilizer recovery by buffelgrass was increased by increasing $N$ application each year, but was unaffected by rate of $\mathbf{P}$ applied. Fertilizer application had no effect on $P$ fertilizer recovery by Pretoria 90 . Annual rainfall received, however, increased apparent $\mathbf{N}$ and $\mathbf{P}$ fertilizer recovery by both grasses, since increasing rainfall increased yield and nutrient removal. Apparent $\mathbf{N}$ fertilizer recovery by buffelgrass averaged $52 \%$ the first 2 years but then exceeded $80 \%$ in 1981 when 4 cuttings were made. However, $\mathrm{N}$ recovery dropped to below $20 \%$ in 1982 when overall yields of buffelgrass were low because of droughty conditions. Apparent $\mathbf{N}$ fertilizer recovery by Pretoria 90 was less than $3 \%$ in the first year since $\mathbf{N}$ was available initially. Apparent $\mathbf{N}$ fertilizer recovery increased during each of the next 2 years to over $70 \%$ but declined to less than $10 \%$ in the final year. Apparent $P$ fertilizer recovery by Pretoria 90 also increased the first 3 years from 3 to almost $30 \%$, then declined to near $10 \%$ the last year.

\section{Conclusions}

Common buffelgrass under subtropical conditions on a sandy upland soil in an established stand gave dramatic yield increases and higher $\mathbf{N}$ content to applied $\mathbf{N}$ fertilization. Yields were also strongly influenced by annual rainfall indicating that both $\mathrm{N}$ and water were major limiting factors in plant growth. An interactive effect occurred between $\mathrm{N}$ and rainfall since increasing $\mathrm{N}$ application greatly improved yields per unit of rainfall, or increasing rainfall greatly improved yield per unit of $\mathbf{N}$ applied. Nitrogen fertilizer uptake efficiency was also improved with increasing rainfall.

Pretoria 90 bluestem was excellent for dry areas with a subtropical climate although mismanagement increased susceptibility to cold injury. Newly planted Pretoria 90 bluestem showed no apparent initial use of applied $\mathbf{N}$ fertilizer, indicating that adequate nutrients were initially available. Pretoria 90 bluestem responses to $\mathbf{N}$ fertilization began to occur in the third year, but were not so dramatic as for buffelgrass.

Phosphorus applications caused some yield increases initially for Pretoria 90 where available soil $P$ levels were low, and for buffelgrass at high $\mathbf{N}$ application levels. Forage $\mathbf{P}$ content increased with $P$ fertilization, but was not sufficient to preclude the need for $P$ supplementation in livestock diets in subtropical areas. Uptake and utilization of applied $P$ remained low throughout the study.

Establishment of improved pastures under subtropical conditions does not require fertilization initially if adequate nutrients are a vailable from previous crop residues. When $\mathrm{N}$ becomes deficient, dramatic improvements in both yield and forage quality can be obtained with $\mathbf{N}$ fertilization. Availability of $\mathbf{N}$ greatly enhances the efficient utilization of the rainfall received in these drier areas.

\section{Literature Cited}

Black, A.L., and J.R. Wight. 1979. Range fertilization: nitrogen and phosphorus uptake and recovery over time. J. Range Manage. 32:349-353.

Bremner, J.M. 1965. Inorganic forms of nitrogen. In: C.A. Black (ed.) Methods of soil analysis. Part 2. Agronomy 9:1179-1237. Amer. Soc. Agron., Madison, Wis.

Conrad, B.E. 1976. Forage and animal production programs for South Texas. p. 42-44. In: E.C. Holt and R.D. Lewis (eds.) Grasses and legumes in Texas - development, production and utilization. Texas Agr. Exp. Sta. Res. Monogr. 6.

Gonzalez, C.L., and J.H. Everitt. 1982. Nutritional contents of major food plants eaten by cattle in the South Texas Plains. J. Range Manage. 35:733-736.

Hanson, C.L., J.F. Power, and C.J. Erickson. 1978. Forage yield and fertilizer recovery by three irrigated perennial grasses as affected by $\mathrm{N}$ fertilization. Agron. J. 70:373-375.

Holt, E.C., and E.C. Bashaw. 1976. Developing improved grasses and legumes. p. 7-9. In: E.C. Holt and R.D. Lewis (eds.) Grasses and legumes in Texas - development, production and utilization. Texas Agr. Exp. Sta. Res. Monogr. 6.

Jackson, M.L. 1970. Soil chemical analysis. Sixth printing by the author, Dep. of Soil Sci., Univ. of Wisconsin, Madison. p. 174-204. (First published in 1958 by Prentice-Hall Inc., Englewood Cliffs, N.J.).

Kissel, D.E., L. Bartek, and L.J. Zatopek. 1979. Apparent recovery of fertilizer $\mathrm{N}$ by coastal bermudagrass on a swelling clay soil. Agron. J. 71:381-384.

Lutwick, L.E., and A.D. Smith. 1979. Yield and N uptake by seven perennial grass species as affected by high rates of $\mathbf{N}$ fertilizer. J. Range Manage. 32:433-436.

McBee, G.G. 1959. Yield and quality of forage produced by nine warmseason grasses grown under a constant fertilizer and irrigation schedule in the Lower Rio Grande Valley. Texas Agr. Exp. Sta. PR-2107.

Prine, G.M., and G.W. Burton. 1956. The effect of nitrogen rate and clipping frequency upon the yield, protein content and certain morphoJogical characteristics of Coastal bermudagrass (Cynodon dactylon (L.) Pers). Agron. J. 48:296-301.

SAS Institute, Inc. 1982. SAS user's guide: statistics, 1982 edition. SAS Institute, Inc. Cary, N.C.

Whiteman, P.C. 1980. Tropical Pasture Science. Oxford University Press, New York.

Wight, J.R., and A.L. Black. 1978. Soil water use and recharge in a fertilized mixed prairie plant community. J. Range Manage. 31:280-282.

Williams, R.J., K. Broensma, and A.L. Van Ryswyk, 1979. The effects of nitrogen fertilization on water use by crested wheatgrass. J. Range Manage. 32:98-100.

Woodward, W.T.W. 1980a. Evaluation of selected forage species for South Texas. Texas Agr. Exp. Sta. MP-1459.

Woodward, W.T.W. 1980b. Performance of buffelgrass cultivars for South Texas. Texas Agr. Exp. Sta. MP-1460.

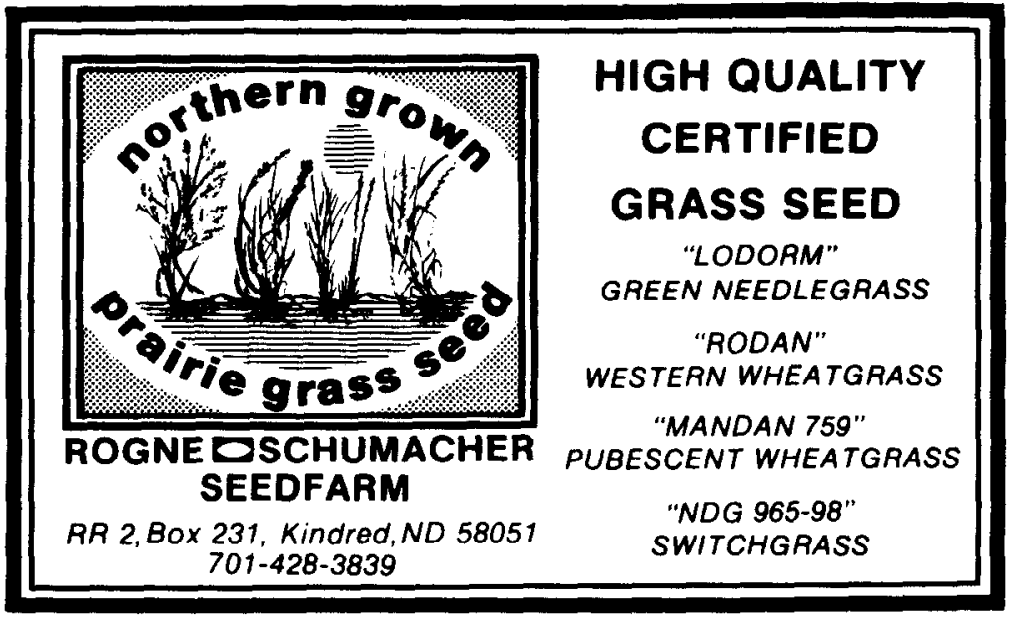

